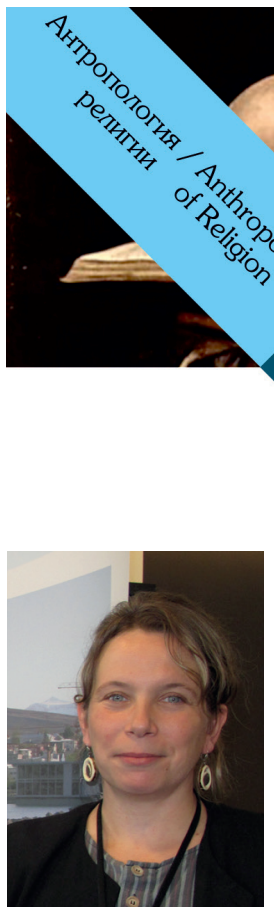

A. Lavrillier

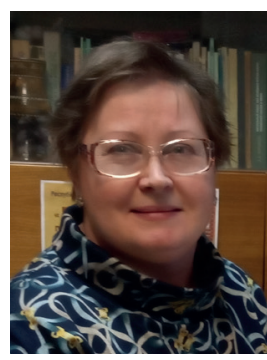

T.Yu.Sem

Религиоведение. 2021. № 3. С. 32-51
Religiovedenie [Study of Religion]. 2021. №. 3. Р. 32-51

DOI: $10.22250 / 2072-8662.2021 .3 .32-51$

${ }^{1}$ Alexandra Lavrillier, ${ }^{2}$ Tatiana Yu. Sem

${ }^{1}$ University of Paris-Saclay ${ }^{2}$ Russian Museum of Ethnography ${ }^{1}$ Paris, France

24/1 Inzhenernaya street, St. Petersburg, 191186, Russia 'alexandra.lavrillier@uvsq.fr semturem@mail.ru

\title{
Contemporary "Shamanising Persons" among the Tungus-Manchu (Evenki, Even, and Nanai): Case Studies about Common Collective Spiritual Representations
}

Abstract. This article studies common spiritual representations about contemporary Tungus-Manchu "shamanising persons". It analyses ethnographic material gathered by the authors between 1994 and 2020 among the Evenki, Even, and Nanai of Yakutia, the Amur region, Kamchatka, Novorossiysk, and Khabarovskii krai, as well as the relevant scholarly literature. Under Soviet anti-religious policies, the traditional shamans of these peoples went into significant decline: the last traditional shamans passed away in the 2010 s, thus potentially disrupting the transmission of the shamanic function. Nevertheless, according to collective representations, the spirits are still active and continue elect people to become shamans. Our paper argues that these peoples are enduring "ritual wanderings", wedged between a lack of individuals able to transmit the knowledge required to become a traditional shaman and the fact they reject urban/western neo-shamanism (in contrast to other Siberian peoples like the Buriat, Tuva, Yakut, and Altai). Through the analysis of a mosaic of case studies on shamanising persons who are neither traditional shamans nor neo-shamans, we reveal many relationships with the spirits, the ways these people deal with shamanic election, and the common core of the spiritual representations of the Tungus-Manchu. This paper contributes to the study of contemporary shamanism, Tungus-Manchu cultures, and human-nature relationships.

Key words: mentality, collective spiritual representation, contemporary shamanising persons, TungusManchus, gathering the spirits, methods of knowledge transmission

\section{${ }^{1}$ Паврилье А., ${ }^{2}$ Сем Т.Ю. \\ ${ }^{1}$ Университет Париж-Сакле ${ }^{2}$ Российский этнографический музей ${ }^{1}$ Париж, Франиия \\ 2191186, Россия, г. Санкт-Петербург, ул. Инженерная 4/1 lalexandra.lavrillier@uvsq.fr ${ }^{2}$ semturem@mail.ru}

\section{Шаманствуюшие персоны тунгусо-маньчжуров (эвенки, эвены, нанайцы) в современном мире: опыт ментальной характеристики}

Аннотация. Статья посвящена общим духовным (ментальным) представлениям о современных тунгусо-маньчжурских «шаманизирующих». В статье анализируется этнографический материал, собранный авторами в период с 1994 по 2020 год среди эвенков, эвенов и нанайцев Якутии, Амурской области, Камчатки, Новороссийска и Хабаровского края, а также научная литература. После антирелигиозной политики Советской власти число традиционных шаманов у упомянутых народов значительно сократилось, а последние традиционные шаманы скончались в 2010-х годах, что привело к нарушению передачи шаманской функции. Тем не менее, согласно коллективному представлению, духи по-прежнему активны и продолжают избирать людей в шаманы. В нашей статье утверждается, что эти народы, во-первых, страдают от нехватки людей, способных перенять знания, необходимые, чтобы стать традиционным шаманом, а во-вторых, они по-прежнему отвергают городской / западный нео-шаманизм 


\section{Антропология религии / Anthropology of Religion}

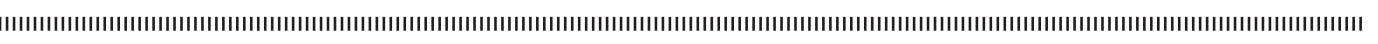

(в отличие от других сибирских народов, таких как буряты, тувинцы, якуты, алтайцы). Благодаря анализу корпуса тематических исследований, касающихся шаманизирующих людей, которые не являются ни традиционными шаманами, ни нео-шаманами, но, тем не менее, шаманствуют по-разному, мы раскрываем множество отношений с духами, а также как эти люди относятся к шаманскому избранию, и изучаем общее ядро духовного представления тунгусов-маньчжур. Эта статья направлена на изучение современного шаманизма, тунгусо-маньчжурских культур и взаимоотношений человека и природы.

Ключевые спова: менталитет, коллективные духовные представления, современные шаманствующие персоны, тунгусо-маньчжуры, собирание духов, способы передачи знаний

\section{Introduction}

While in the 1990s and the 2000s the Evenki and Nanai did not recognise the western-influenced neo-shamanism developing among other Siberian peoples like the Buriat, Tuva, or Yakut, we observed the existence of what we call "shamanising persons" among the Evenki, Even, and Nanai, "individuals shamanising without traditional/neo shamans" [Lavrillier, 2005, 519; Bulgakova, 2013, 222]. Today this has evolved with various practices and beliefs that peoples have adapted through their own cultures and ritual knowledge. These are different and similar to traditional shamanism, but also distinct from neo-shamanism.

In the contemporary world of Siberian indigenous peoples, shamanic knowledge is relayed to the descendants of shamans and those involved in sacred knowledge. Shamanism is characterised by a holotropic and holistic worldview, a particular relationship between man and the universe. Studying contemporary forms of shamanism in Siberia, V.I. Kharitonova [Kharitonova, 2006, 41] notes that among persons currently involved in shamanism, there are several categories: shamans, shamanising individuals, and shamanists. The latter are included in processes related to sacred knowledge in a distinct way. The very idea of the shaman has acquired new content: "there is a shaman in each of us" [Kharitnova, 2006, 6]. Therefore, as shown in Sem's material, a peculiar category of the shamanising person appeared. They have not undergone initiation: they themselves learn shamanic knowledge through prophetic dreams, traditions, and the figurines of helper spirits.

Based on numerous case studies observed in southern/northern Yakutia, the Amur region, and Kamchatka between 1994 and 2021, Lavrillier will summarise practices with and without traditional shamans, followed by a typology of shamanising persons from 2000 to 2020: these individuals are neither traditional shamans nor neo-shamans. Sem then will describe two case studies of Evenki and Nanai shamanising persons based on field materials from the Krasnodarskii, Tambolskii, and Khabarovsk krais from 2003 to 2020. We conclude by discussing the contemporary collective spiritual representations of Tungus-Manchu shamanising persons.

\section{The Evenki and Even of Yakutia, the Amur region and Kamchatka}

In Yakutia, the Yakut often state: "All Evenki and Even possess shamanic power" or "they are all shamans". After the Russian conquest of Siberia, attempted Christianisation, years of communism and anti-religious campaigns ${ }^{1}$, and the resistance of a few shamans during the Soviet period, traditional shamans have now disappeared, as far as we know. Due to strict prohibitions and repression by the Soviet authorities, most collective shamanic rituals, like the famous Evenki Ikenipke, stopped in the 1950s (eastern Siberia). During sedentarisation, the installation of western medical centres in villages probably also contributed to the reduction of shamanic rituals. Nevertheless, the Evenki never stopped daily individual rituals related to domestic life, the life cycle or reindeer herding. Similarly, they never stopped perceiving their surroundings (be they natural or not) as inhabited by a multitude of spirits. After the collapse of the Soviet Union, most Siberian peoples wanted to strengthen their connections with the spirits.

We analyse different types of shamanising persons, including some that correspond to Tungus traditions: we thus prefer not to apply the term neo-shaman(ism) to our case studies. Indeed, the latter is more often defined as intensely influenced by Western movements (as in M. Harner or C. Castanieda) and is centred on concepts of personal development, New Ageism, and universality. It is institutionalised via associations, consultation centres, and pricing: the shamans are self-elected [Mandelstam Balzer, 1993; Hamayon, 2003, 10; 2015; Stepanoff, 2002; Kharitonova, 2006; Merli, 2007, 100]. 


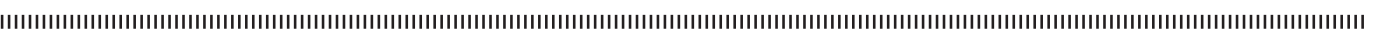

\section{Changes in traditional Evenki shaman practices from the 1950s to the 1990s}

In collective Evenki representations, shamans cannot live or practise rituals in towns far from taiga, the residence of the main shaman spirits. To them, people who order their costume from urban theatres cannot be shamans. "Nature itself makes the shaman!", they say: "Shamans need silence, they gain power from nature in the quietness (with no mechanical or electronic items and few people around); even in small villages, they cannot live!" [Lavrillier, FN 1990s-2020s; 2005]. In the 1990s in Iengra (Yakutia), the traditional shaman Matriona Kulbertinova was actively practising shamanic rituals in the forest, where she spent all her life herding reindeer and hunting until she died in 1996: she could not bear the village. The "last" traditional Evenki shaman of eastern Siberia, Savelii Vasilev (Iengra), passed away in 2012. Vasilev required switching off televisions, radios, and electric lamps during his rituals, because these hindered his trips to other worlds and his interactions with the spirits. He spent most of his life herding reindeer in the taiga [Lavrillier 2005, 493-497; see Bulgakova, 2013, 222 about the Nanai; Sem, 2017, 217 231]. Zabiyako also describes Vasilev's life at length [Zabiyako, 2012, 249-255].

While everyday nomadic life is full of ritual gestures, most of them cannot be performed in villages or towns. Indeed, in these places, considered "empty of the natural environment's spirits", only the spirits of deceased humans who did not reach the world of the dead wander. These terrify nomads [Lavrillier, 2005, 329 et passim]. In contrast, the Tuva, for instance, practise many rituals in towns, making offerings to the spirits through open windows or electric hobs [Rojo, Chondan, Chondan, Lavrillier, 2016].

From the Soviet period to 2012, the Evenki have appealed to shamans when modern western medicine has been unable to treat the patient or in cases of huge problems in life, herding, or hunting. An important part of shaman rituals occurred during the "feast of the reindeer herders", when the shaman and most nomads joined the village. But the rituals that require the most "powerful" spirits should be held in the taiga at night, far from villages or towns. The shaman's attributes (personal items) should leave the nomadic camp only during the ritual. At the end of rituals held in the village, the shaman would choose a young nomad to take the attributes back to the forest. These traditional shamans refused payment for their rites. Rituals had to have as many participants as possible in addition to the "patient". Everyone had to participate by singing, repeating the shaman's words, taking the drum beater, etc. The traditional shaman did not shamanise full time, but relied on hunting and herding. The rituals were exclusively oral and attributes were made of wild animal materials and metal. These shamans refused to participate in the collective "revivalist rituals" initiated at the beginning of the 1990s [Lavrillier, 2003, 2005, 432 et passim].

While the shaman used to have the duty of obtaining luck in hunting and protecting the reindeer and people of his own clan/nomadic group, the only shaman still practicing from the 1990s to the 2010s had to serve many more people (i.e. members of villages and regional groups). Moreover, a shaman could become, often in spite of himself, a sort of ritual symbol of an entire people. When two Evenki shamans were still active, they refused to perform rituals for people who were not part of their clan or associated with it. Thus, some Evenki not associated with the shamans' kinship groups preferred not to address shamans at all. However, since the deaths of these two shamans (1996 and 2012), all the Evenki have started waiting for new traditional shamans or pseudo-shamans to appear [Lavrillier FN 1990s-2010s; see also Zabiyako et al., 2012, 249]. This quest may explain the appearance of the many types of "shamanising person" observed by the authors in their respective fieldworks.

Lavrillier [Lavrillier, 2005,417-523] observed at the end of the 1990s and beginning of the 2000s among the Evenki a major break in the transmission of the shamanic function, just as among many other Siberian peoples [Mandelstam Balzer, 1993; Hamayon, 2003; Vitebsky, Alekseev, 2015, 448]. For the Evenki, the only shaman living in the 2010s was not enough to transmit the shamanic function. The traditional shaman Kulbertinova on the eve of her death transmitted her "knowledge" to her granddaughter, but the latter died five years later. This untimely death was interpreted as meaning that "she had failed to win over the shaman's spirits". Before dying, the shaman Vasilev said that a man from the Vasilev clan would receive his shamanic function, but nobody has yet proved to possess this heritage. 


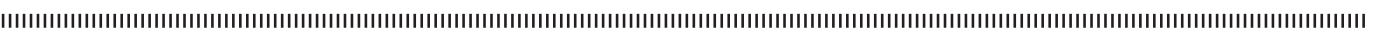

The transmission of the shaman function is difficult to achieve today. Furthermore, the traditional shamans and their children met by Lavrillier have stated: "Being $a$ shaman is very painful and I do not wish anyone, not even my worst enemy, to have to fulfil this function!" [Lavrillier, 2005, 442; Bulgakova, 2013].

Another hindrance to the emergence of young traditional Evenki shamans is the scarcity of people able to make costumes, drums, and shaman's attributes. Such individuals not only master shamanic items, but must also confirm future shamans for the community. To the Evenki, the shaman exists thanks to the people who elect him/her, make his attributes, and assist and guide him during the rituals (see below). Likewise, the shaman's wife or a female helper played a crucial role. The spouse was the guardian of the shaman's soul: she coordinated parts of the ritual and in case of "danger" she removed the shaman's shoes to hit his face and bring him back to the middle world. To the Evenki, it is dangerous to address a shaman without a good female helper: this risks the shaman's life and those of patients [Lavrillier FN 1990s-2000s].

Evenki nomads and villagers strongly desire traditional shamans again. They often express: "When there were many shamans, the Evenki lived happily and with good fortune!" [Lavrillier FN 1994-2020; see also Zabiyako et al., 2012, 256]. Note that the Nanai and Evenki (according to Shirokogoroff) thought they risked collective disease/crisis when the clan did not have a shaman [Bulgakova, 2013, 37-39]. Lavrillier noticed that urban Evenki (mostly intellectuals) express a feeling of guilt (undoubtedly of Orthodox origin) towards the spirits neglected during the Soviet period. Despite this desire, from the 1990 s to the 2010 s the Evenki were unable to create new shamanic vocations according to tradition, but they still rejected neo-shamans in contrast to the Tuva, Buriat, or Yakut.

\section{The collapse of communism:}

\section{the emergence of new types of shamanisms and shamanising persons}

The ideological vacuum and economic crisis left by the fall of communism led to a desire to "rediscover one's own traditions", but in different ways and for different reasons [Le Berre-Semenov, 2008, 209-333; Vaté, 2005; Varlamov, Keptuke, Lavrillier, 2020]. With the economic crisis, the Evenki nomads mainly relied on natural products. They began to practise hunting, herding, domestic rituals, and sacred prohibitions/proscriptions much more than during the 1970s, a period with good salaries and sufficient supplies from state farms. Indigenous intellectuals explain: "Our generation was taken as young children from the nomadic world. Educated in schools and receiving university degrees, we had to trade our traditions for communist ideology in which many of us believed, but anyway, we had no choice. The Russians returned to Orthodoxy and we reconnected with our spirits and traditions!"' Thus, several types of shamanisms coexisted between the 1990s and the 2010s. 1) Those Evenki nomads whose system of thought remained sufficiently intact only accepted traditional shamans and rejected neo-shamans. 2) The villagers and townspeople whose way of thinking was sufficiently impacted by the Western worldview accepted the reconstruction of rituals linked to movements of "return to tradition", which served, among other things, to "prove" their identity vis-à-vis other peoples or reunite an ethnic group scattered across a city. These were two ways for natives to face anxiety: "If we live so badly, it is because we do not respect our spirits enough. But how can we reconnect with them? We hardly have a shaman anymore and we have almost forgotten our collective rituals?" [Lavrillier, 2003; 2005, 335-413, 439; 2020, 73; about other Siberian peoples see: Le Berre-Semenov, 2008; Bulgakova, 2013, 150 et passim]. To Sem, this is primarily due to the need to reproduce cultural memory based on ancient traditions, a process driven by the Siberian ethno-cultural mentality and identity construction.

In this specific context of Soviet collapse, Lavrillier observed an increasing number of co-existing "shamanising persons" who were neither traditional shamans nor neo-shamans.

\section{The shaman showmen}

The number of traditional nomadic healers and diviners fulfilling certain therapeutic or divinatory functions of the shaman has increased. Lavrillier also noted the emergence/increase of a category of ritual specialists, the "shaman showmen" (her term). During the Soviet period, the first generation of shaman showmen were mostly true shamans who agreed to show shamanic rituals on a theatre stage as a form of anti-religious propaganda; thus, they escaped repression. The Soviet authorities thought that this would 
make the rituals seem nonsensical to the natives. In Siberia in the 1990s, several shaman showmen toured Russia and the world to hold shamanic sessions during conferences and cultural concerts, sometimes with the help of anthropologists like Vitebsky and Alekseev. Traditional singers, storytellers, and the children of shamans make up a second generation of shaman showmen. Some of first- and second- generation shaman showmen were secretly recognised by the local population as effective shamans or healers. This was the case for $\mathrm{S}$. Vasilev or Demnin Kosterkin and his son Delsumiaku among the Nganassan [Lecomte, 2012]. Some second-generation shaman showmen (not the recognised shamans) were actively involved by intellectuals in "revivalist rituals" to perform important offerings, sacralise reindeer, play drums, etc. [Lavrillier, 2003b; 2005, 410-427]. After a few years of practice, some of them claimed that they had become shamans. Nevertheless, their functions differed from those of the traditional shaman. Their status is more like that of an elder who can conduct some individual and collective rites. The ability of some elders to perform important rituals was acknowledged in the ethnographic literature of the $19^{\text {th }}$ and $20^{\text {th }}$ centuries [Vasilevich, 1930; 1957; Shirokogoroff, 1935].

\section{A new shamanism of elders?}

Evenki elders and shaman showmen mainly participate in great collective revivalist rituals (ikenipke, bakaldyn): some of them are recognised as diviners or people able to change the weather. They are the organisers of collective rituals; they also make offerings to the spirits and pronounce "ritual wishes" for the community. They are villagers, but they inherited traditional knowledge from their shaman (grand)parents, whom they assisted for many years. These ritual specialists often straddle two cognitive worlds: they have travelled all over Russia and/or the world and many have completed university studies, but, at the same time, they are very close to their own ancient culture. They often express the desire to save their people from a spiritual void. Their services were free in the 1990s and 2000s, but in the 2010s some of them required payment. This activity only occupies a small part of their time. Their practice is only oral, although they write the scenarios of revivalist rituals, booklets about traditions, and ethno-historical accounts of their community. Their costume is reminiscent of that of traditional shamans, but without metallic representations of the spirits ${ }^{3}$. These elders or shaman showmen insist that the rituals should take place far from the city or village, in a world reminiscent of the forest. Some of them conduct such rituals in ethno-tourism centres [Humphrey, 1996; Lavrillier, 2005, 376; Varlamov, Keptuke, Lavrillier, 2020, 63].

Sem took part in such a winter revivalist ritual in 2001 near Yakutsk, which was organized by G. Varlamova, an Evenki epic poetry specialist with shamanic roots. A. Myreeva conducted the ritual with the head of the local Evenki association. A yurt was installed, a fire was lit in it, and it was fed. Then a reindeer figure made of larch branches was symbolically shot (i.e. Sinkelavun/Shingkelavun ritual). A round dance was organized, followed by a lunch with reindeer meat.

\section{Flourishing Yakut neo-shamanism}

From the 1990s, Lavrillier studied the emergence of neo-shamans among the Yakuts surrounding the Tungus. At the beginning of the 1990s, the Yakut government supported the publication of books written by neo-shamans/ritual specialists to promote a blend of their tradition and trendy spiritualties from the West. They created an association of "traditional healers" (in which most traditional shamans refused to participate) with a website. They opened consultation offices in towns and organised treatment stays in certain specialised centres. These neo-shamans relied on such consultations. Their books advocated a "return to shamanism" and "proscriptions from the ancestors" (aiyy uerette in Yakut) to "fight against the scourges of alcoholism, delinquency, corruption, and globalisation, which are raised by some spirits looking devilish", as the Yakut neo-shaman V.A. Kondakov wrote. The cosmogony they presented was a mixture of traditional Yakut elements (selected from ethnographic literature), Judeo-Christian elements (like the notion of punishment, demons and angels), and borrowed concepts (i.e. bioenergy, yin and yang, etc.). These neo-shamans travelled a great deal and met many Buriat, Tuva, Altai, Mongolian, and American neo-shamans: they were in close contact with an organisation created by M. Harner, a former American anthropologist, for training neo-shamans (Foundation for Shamanic Studies, US) [Mandelstam Balzer, 1993; Kharitonova, 2006]. While 


\section{Антропология религии / Anthropology of Religion}

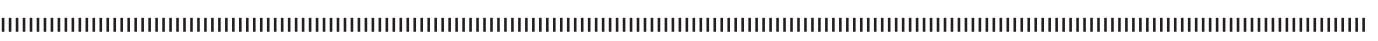

most of the rural population were sceptical, part of the Yakut townspeople recognised these urban neo-shamans. In contrast, the Evenki and Even rejected them. The narratives of Evenki/Even traditional shamans, shaman showmen, and elders-ritual specialists depicting Yakut neo-shamans met during cultural events as having nothing shamanistic or being very weak influenced this rejection. "Any Tungus is more of a shaman than these Yakut neo-shamans", they repeatedly stated [Lavrillier, 2003a; Lavrillier, 2005, 220-518].

These types of shamans and shamanising persons coexisted, but in no case did they mingle during the same rituals in the 1990s and 2000s. Thus, a neo-shaman could not participate in the same ritual as a traditional shaman. But this changed in the 2010s, when, for instance, S. Vasilev invited a Russian neo-shaman to a ritual in 2011. The local Evenki strongly disapproved of this, just as they disapproved of their traditional shaman's trips around the world: "this exhausts our shaman and his soul because of the various spirits in the world" [Lavrillier, 2005, 335-523].

In the 1990s and 2000s, each of these types of shamans and shamanising persons corresponded to the various needs of nomads, villagers, and townspeople.

\section{Are all Evenki shamanising persons?}

Lavrillier [Lavrillier, 2005] questioned the possibility for the Evenki to continue shamanising without shamans. Based on many months of fieldwork, she found that shamanising persons can be ordinary individuals according to the native concept of onnir. Onnir is made up of a number of beneficial and harmful spirits contained within human individuals and certain animals: these spirits empower them to act and perform rituals. This number varies due to life events, experience, the practice of talents, and the knowledge and practice of handicrafts, economic activities, or rituals. These spirits manifest themselves through a talent (singing, dancing, decorating, drawing, storytelling, writing, hunting, herding animals, caring, playing an instrument, performing rituals, etc.), and everyone has to learn how to "make good use" of these spirits. Through such practices, individuals improve their mastery of their onnir's spirits and increase their ritual power. In this exercise, the shaman is considered to be the strongest. As it is attributed to humans (and some animals), this "spirit charge" is deemed to leave what Lavrillier terms an "active imprint" on beings, items, and actions. This explains why not only shamans, but also elders and other persons can shamanise [Lavrillier, 2005, 267-280, 492-520; 2020; $2007 \mathrm{a} ; 2007 \mathrm{~b}$. To Sem, this concept of onnir, is partially reminiscent of naualaku: young gifted individuals, shamans, successful hunters, or men who receive a guardian spirit in a dream or during a solitary vigil in the forest [Токарев, 1964, 306-322; Mauss, 1991; 340-345]. Evenki round dances or wishing songs clearly state that one can shamanise without shamans: "Let us dance the delehincho, laughing will allow us to go on and live! Come here and let us shamanise all together!'” sang Prokopii E. Nikolaev, a shaman showman from Tiania ([Lavrillier, Lecomte, 2002], recorded in 2000 during a Evenki meeting at the edge of Yakutsk) (Illus. 1).

"In the middle world, in the light of the sun, living beings walk. Now, sitting in my tent, I will sing for my children; With a drum and a beater, I, the grandfather, would have sung for the future of my children; they would have watched the singing shaman, they would have taken the beater and repeated after me [my shamanic words to the spirits], but now we have gathered and we sing: go well into the future! Keep my words in your minds and do the rituals well!" sang Vladimir S. Andreev ([Lavrillier, Lecomte, 2002] recorded in 1997 in the nomadic area of Ust-Niukzha).

Nevertheless, the onnir's spirits can be harmful if not controlled. There are many stories in villages

Illus. 1. The Evenki shaman showmen P.E. Nikolaev and V.S. Neustroeva performing a collective ritual of purification with drums (2000, taiga close to Yakutsk). Picture: A. Lavrillier.

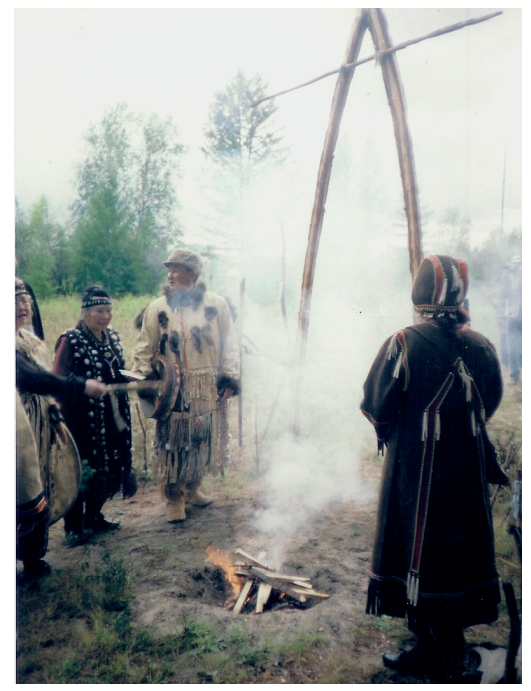


and forest about some people who are said to have inflicted (intentionally or not) pain and accidents on others just by thinking about it. It is said that rows or bad words must be avoided with/towards them, lest they act harmfully toward the person responsible. They are said to own within themselves dangerous spirits they do not control, and people fear them [Lavrillier FN 1990s-2010s, 2017]. They are not seen as shamans because they cannot control their onnir's spirits and can be malevolent [Lavrillier, 2020, 81, 89, 90].

\section{In search of traditional shamans}

The Evenki and Even's desire to have traditional shamans can explain why in everyday life discourses about shamans are omnipresent, giving the impression that traditional shamans still exist. These discourses evoke past shamans in local kinship groups, the places of shaman graves and related proscriptions and prohibitions, dead shamans' attributes, impressive shamanic sessions, the predictions of past shamans, future or potential shamans, fights between shamans who take the forms of wild animals, and "shamanic suicides" (see below).

Increasing in number during the 2010s, the many figurations of shamans in theatrical performances by Tungus dance groups during revivalist rituals (ikenipke, bakaldyn, evinek, nurgenek) and meetings also compensate for this lack of traditional shamans. Often, a child dressed in a representation of a shaman's costume with fabrics, a drum, and a beater will mimic a shamanic ritual or legend; other children represent spirits and humans. The elders approve of such representations of the shamans: in 2020, P.S. Neustroev, the son of one of the strongest shamans in Iengra from the 1950s to the 1970s, considered the many children representing shamans on stage during a concert at the feast of the reindeer herders to be an auspicious ritual action [Lavrillier, 2005, 350-366, 437-439, 492-515; Lavrillier FN 2020; about the Nanai, see Bulgakova, 2013, 152-165].

\section{Those who can become shamans}

Many Evenki narratives from the 1990s talk about nomads who could become (or felt the need to become) shamans: many were the (grand)children of shamans. Their stories show various profiles. Some of those recognised as traditional healers (with plants, animal elements, hypnosis, or the application of hands) expressed the difficulty of healing the many people constantly requiring them and bearing their accumulated pains. Just like traditional shamans, they were unable to use their talents for personal purposes or gaining income, but only to help people. A son of shaman, a master of many handicrafts who knew well the shamanic rituals, could make drums for others, but not for himself. He regularly provided people with divination and could intentionally act ritually for the benefit or harm of others. Regularly he asked people to make him a drum so he could become a shaman, but nobody did [Lavrillier FN 1998-1999]. Others were epic poetry tellers and by this activity treated people like shamans [Lavrillier, Matic, 2013, 6-10]. Others were nomads with extraordinary hunting luck, a sign of a specific agreement with particularly powerful spirits. The souls of such "super hunters" (Lavrillier's expression) travelled during the night and convened with shaman souls dozen kilometres away (just as shamans did between themselves). Health problems among these hunters, like sudden blindness, deafness, or death, were interpreted as the results of their inability to become shamans. All the communities believed these persons could become shamans because their grandfathers were strong shamans who never acted ritually to harm people. "He might become a shaman, but somebody spoiled his chance. He asked an elder from a strong shamanic clan (a clan decimated during the anti-religious repression) to make him a drum, but the latter postponed this task for five years, during which time this great hunter lost his shamanic force", explained the nomads. These people have never healed anyone [Lavrillier FN 1998-1999]. Note the several examples from the 1990s and the 2000s when the absence of drum made it is impossible to be a shaman. Sem worked in 1994 with the shaman Vasilev and asked him to do a ritual for her. He refused, arguing that his attributes were in a winter camp in the forest, very far from Iengra. Later, these attributes were seen in a video recording of a seance held by Vasilev. Thus, the drum and costume are indispensable for ritual performances.

\section{Failed shamans after trying with drums and costumes}

In 1998-1999, Lavrillier collected stories about people who were elected by the spirits to become shamans at the end of the 1970s and beginning of the 1980s, but were 


\section{Антропология религии / Anthropology of Religion}

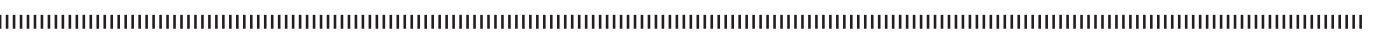

unable to win over the spirits: they became mentally disturbed and committed suicide. People said they really might become shamans. They had shaman ancestors and suffered from regular shamanic attacks. The communities decided to see if they were ready to become shamans and made them drums and costumes. They attempted to perform shaman rituals in front of the nomadic community in the taiga, led by the elders who had made the shamanic attributes and knew such rituals. But people were not convinced by these efforts and the failed shamans lost their minds. After this, their communities attributed to them the ability to act malevolently on people, including by provoking death. Over many years, the Evenki expected their descendants to become shamans: some have even seen how their descendants' souls (shadows) arrive long before themselves when visiting a house [Lavrillier FN 1998-1999]. Zabiyako gives a similar example from the village of Bomnak [Zabiyako, 2012, 255]

\section{Potential shamans hindered by traditional shamans}

Between 1995 and 2000, Lavrillier noted stories about fights between the souls of potential and traditional shamans. In 1998, while visiting Tiania (southern Yakutia) the Evenki shaman S. Vasilev in a dream fought the soul of a local person "becoming a shaman". She started in 1995 to treat people with great success at the age of 30 after winning over the spirits responsible for her own illness. All Tiania's villagers and Vasilev's supporters were still commenting on this fight several years later. Lavrillier noted a similar story in 1995 when Vasilev stayed in Kindigir: the fights were followed by the suicide of the three people "becoming shamans". Similarly, in Khatystyr in 1998, a female Evenki shaman's soul attacked Vasilev's soul: they had a long fight that was violent "to such extent that the door in the room suddenly shattered when she attacked S. Vasilev". From this moment onwards, Vasilev informed all the Evenki of several villages about the existence of this young, strong shaman: at the same time, he underlined that he was the strongest. The nomads explained that this young person could never become a shaman because Vasilev defeated her: she would get sick, go mad, die, or become harmful.

\section{Pseudo-shamans and prophets}

At the end of the 1990s and beginning of the 2000s, "pseudo-shamans" and "prophets" (Lavrillier's terms) appeared among the Evenki. One Evenki, always living in the taiga without reindeer, little food, and few goods, predicted from 1997 to 2000 an important shift in the path to the new millennium (in varying versions). He explained, "the god Seveki will come soon to the top of our mountain and will make a revelation to the Evenki. I will then stop walking around the forest to visit the rock paintings over hundreds of kilometres in order to predict the future, as he commissioned me". After a year, he predicted that in 2000 a new planet (twice the size of the Earth) would come and the Evenki would migrate to it for a better life. As he put it: "The Evenki will live twice as long as on Earth. There will be much game and domestic reindeer. I am in charge of organising this migration. After people move to the new planet, I will stay and with the ichchi [malevolent spirits from the souls of the deceased who did not reach the world of the dead], I will guide the domestic reindeer to the new planet. This planet is situated close to the bright star appearing at the beginning of the night, close to the horizon" [Lavrillier FN 1997-1999]. These narratives were very popular until 2000 and circulated around the nomadic camps and villages. For several years, the Evenki considered this man as a potential future shaman, and he fulfilled the role of a pseudo-shaman. They attributed to him some shamanic power. Thus, judging by his tracks on the snow, it was obvious to them that he was flying. There were human tracks, which then changed into bear tracks: than there were no more tracks, with signs of this person only reappearing a few kilometres distant. Some nomads witnessed him in the taiga drinking and conversing with many "Evenki who they have never seen before and do not need fire", a canonical description of ichchi spirits present in many "ichchi stories", a nomadic institution of nocturne palavers. Ichchi terrify ordinary nomads, so seeing a person talking with them was a hint of his shamanic power, as were his abilities to take the form of bear and to fly. Likewise, he never had matches, but always took with him a hot coal to light a fire. He declared that he had no reindeer because the ichchi would not allow him to herd them. This person distinguished ichchi-angels from the ichchi with whom he was fighting: he destroyed the latter with lightning bolts and thunderstorms. Nomads said 
he had been a normal person, but when he was 40 years old, he came back from hunting to the tent and stated Seveki had given him a mission [Lavrillier FN 1997-1999]. In the past, Evenki shamans and hunters made tours of rock paintings for the purposes of divination. Rock paintings were said to be the work of Buga, the spiritual entity of the natural environment [Lavrillier, 2005, 450-453], or of Enekan Buga, the spirit of the universe itself: making offerings at these places was a part of crucial rituals, including the sinkelavun/ shingkelavun [Anisimov, 1958, 29; Tugolukov, 1975, 42-44; Mazin, 1984, 12, 23, 94].

The pseudo-shaman explained: "Once, this Seveki appeared to me in my tent: a very old man in a long dress, very tall. I got lost and did not know how to deal with him. I remembered in my childhood that I saw a Russian granny making the sign of the cross. I did this in the direction of this god. Suddenly, the latter became smaller and smaller, and disappeared under the wood-burning stove. I looked under the stove and saw the blue skythe god had vanished". The other nomads extensively retold his stories: some believed him, others not, but all attributed to him exceptional physical force, a feature of traditional shamans (see below). Despite a certain recognition of him as a shamanising person or a potential future shaman, he was never considered a shaman and did not receive a drum (although some of the elders could have granted this). Lavrillier's analysis of the discourses about him shows that important obstacles for him were the lack of shaman ancestors, the fact that he possessed nothing, that he was not a master of any handicraft, and because "he did not win over the spirits", to quote the Evenki. At the beginning of the 2000s, when people stopped believing in him as a future shaman, the elders remembered: "his grandfather had similar behaviour, and his sister is a good singer of traditional songs" (attributed with ritual efficiency [Lavrillier, 2007b], "while his brother is said to act ritually upon other people by simple intentional or non-intentional thoughts" (also ritual powers). In 1999, other stories were told about real people who were supposedly able to fly because their grandparents were shamans [Lavrillier, 2020, 81, 89; Lavrillier FN 1997-2000].

\section{No more traditional Evenki shamans -}

\section{towards the neo-shamans of ethnically related peoples $(2010 \mathrm{~s}-2020 \mathrm{~s})$}

From the 2010s and the gradual cessation of the "last Evenki shaman's" (S. Vasilev) ritual activities, Lavrillier observed that step by step Evenki started addressing some neo-shamans, mostly from indigenous peoples relatively close to them, like Khamnigan, the Evenki of Buriatia, or Buriat ${ }^{4}$. A shaman with a typical Buriat shamanic costume and ritual gestures (like milk aspersion) ${ }^{5}$ was invited by an Evenki leader first for personal problems and then to the revivalist ritual bakaldyn in 2010, a festival full of reinvented ritual gestures [Lavrillier FN 2000s-2010s; Zabiyako et al., 2012, 256-258].

After Vasilev's death, some of the elders who had said before that neo-shamans are not shamans (see above) not only started to turn to such people in Yakutsk, but also accepted the notions of paying for treatment and receiving shamanic healing over the phone. Despite the belief that neo-shamans were/are not shamans, local Evenki are convinced that these interactions between Evenki elders and neo-shamans from other indigenous peoples mobilise very powerful spirits, triggering severe consequences. In 2019, an elder with serious cardiac problems addressed a Yakut shaman from Aldan. But people told that through this ritual, the Yakut shaman pushed the elder's nephew into the world of dead in the elder's place in order to heal the latter (a ritual process called anacha in Evenki). "There are many such shamans among Yakut", the Evenki declared. After the nephew's tragic death, the elder recovered strangely well from his heart attack. People criticised the fact he had sought a non-Evenki neo-shaman. Similar to Yakut neo-shamans, some Evenki elders are attributed with the ritual power to push their younger relatives into the world of dead so that they can live longer. People really fear such elders. Such behaviour is also seen amongst shamans themselves: the Evenki say that a fight between a current shaman and a future shaman was followed by the death of the vanquished future shaman (see above). Likewise, people strongly criticised Evenki elders who turned too regularly to non-Evenki neo-shamans, an activity deemed dangerous to the lives of the elders' relatives. This was compared to the shaman showmen or healers mentioned above, who, as explained, "lost a lot of their relatives by over-shamanising". So, we see that even when there are no more traditional shamans, belief in the spirits and the shamanic power of non-shamans is active among all generations [Lavrillier FN 2000s-2020]. Similarly, as 


\section{Антропология религии / Anthropology of Religion}

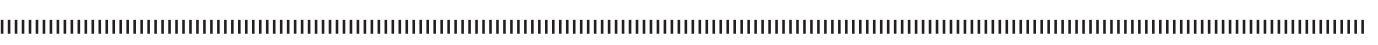

noticed by Bulgakova [Bulgakova, 2013, 103-164], the Nanai started to become interested in having their own new types of shaman.

To Sem, contemporary neo-shamans, much like ancient shamans, aim to interact with the powers of nature and the universe by maintaining harmony and balance. The balance between nature and society is maintained through the construction of the universe and interactions with it, as well as the transfer of the external world into the human psyche [Sem, 2011, 441].

\section{Healers with shamanic powers and budding shamans borrowing Western approaches}

The Evenki and Even nomads repeatedly mention the ability of some individuals to treat furuncles, warts, headaches, joint pain, etc., just through the application of hands or by manipulating traditional medicine. They specify that gestures alone are not sufficient: the efficacy of the healing comes from the individual, from his/her onnir [Lavrillier, 2005; 2020]. Healing must be for free.

Some other Tungus individuals combine their shamanic power with approaches borrowed from the West (yin/yang, biopol (bioenergy), numerology, astrology, lithotherapy). They are also talented in various handicrafts (cf. onnir above). They charge affordable prices for consultations. Note that all these persons are close descendants of shamans, a feature their relatives always underline. An individual highly recognised among the Tungus (including elders) and Russians for his treatments started working in 2013 after the death of the last Evenki shaman. In his maternal and paternal lines, he has very strong shamans who, as those who surround him believe, allow him to treat people. He calls upon the souls of his ancestor shamans when healing. His relatives wanted him to become a traditional shaman and thought to turn to the children of shamans who knew the rituals well. But finally, they believed this to be too dangerous for their budding shaman: "He has no 'totem'for defending himself. A 'totem' is the animal-spirit (like sable, eagle, bear, etc.) that defends the shaman against 'other powers'. In contrast, the children of shaman who helped during rituals do have powerful spirits, which are potentially very dangerous", they explained. His relatives did not know how to raise a "totem" to defend their budding shaman [Lavrillier FN 2013-2020]: see below for Tungus-Manchu totems.

Thus, shamanic power can be inherited without the defending spirits indispensable for becoming a shaman. Ordinary persons in the past could receive defence. Indeed, all elders and youth for whom a traditional shaman performed received a "protecting item" (wooden figurines of birds or other animal, pieces of fabric, fur, stones, needles, wolf tail hair, etc.) in which the shaman installed a "guardian spirit". A person had to always keep this with them and treat it properly in order to receive health and wellbeing (on the Orok, see below).

In 2015, a budding shaman was treating an elder. The latter decided to show one of his "protecting items" made by a shaman when he was two years old. The budding shaman identified the source of the health problem: this protecting item was empty of power, and so he ordered the elder to show it to the full moon ${ }^{6}$ to recharge it and reactivate the protection, which he did. As a result, the elder recovered. This story was very popular and contributed to the confirmation of the budding shaman. The point of view of the elders is very important for the popular recognition of shamans. Such budding shamans are in high demand and treat many people (Evenki nomads, villagers, townspeople, a few Yakut, and Russians): "this demand is difficult to bear", they say. Indeed, they must take on themselves the illnesses and issues of patients, which leaves them tortured by headaches, for instance, despite specific rituals to remove these burdens. "So, if such budding shamans become traditional shamans in the full sense, they will suffer even more. In principle, it is not difficult to order a costume and drum in Yakutsk to help become a shaman," their relatives express. This could be a reason not to become a full shaman and thus may explain why there are more shamanising persons than shamans ${ }^{7}$.

From her 1986 expedition among the Orok (Uilta) (Sakhalin), Sem brought to the Russian Ethnographic Museum a figurine of a seven guardian spirit made by the last shaman for M. Mikheeva during an illness. Since she recovered, she considered it permissible to give this item away. Before she did so, however, she performed a special ritual. She took the seven (a wooden anthropomorphic figurine wrapped in seal fur) attached it to a leather 
string and began to swing it, speaking to it as she did so like a living person: "Go to the museum, there you will be well, people will take care of you" [Sem FN 1986].

To Sem, Vasilev received a defender spirit 'totem', a bear (since he was part of the bear shaman category), after his third consecration at Baikal shortly before his death. Sem analyses Tungus-Manchu categories of shamans in terms of their defender animals (totem). There are beginner shamans (the snake category), those able to see spirits or future (the bird category: cuckoos, owls), healers (the deer or bird-deer category): these animals are the shamans' doubles which travel through the worlds of the universe. There are also mid-level shamans, storytellers and burial specialists at the campfire (ningmata, hergechi). The highest shamans belong to the bear, tiger, or eagle categories [Сем, 2004, 343-349].

The budding Evenki shamans studied by Lavrillier live off other income or main jobs, but such shamanising acts still improve their purchasing power. Sometimes, they canvass new villages with healing announcements, successfully or not. They also use borrowed approaches like western astrology, numerology divination, and consultations via the internet or phone to attract new patients and gain more income.

According to their relatives' accounts, before they became budding shamans and starting to heal people, these individuals were ill, suffering a lot both physically and from shamanic mental states (irilda, togheida). They were found crossing cold rivers naked or in the forest, where they disappeared for days without food. Some narrate how by treating people a budding shaman was cured of a bone defect. After several years of shamanising, they observe their ritual power was strengthened, for instance by gaining the ability to force events to happen just by thinking about them (cf. onnir above) [Lavrillier FN 2013-2020]. This is reminiscent of the physical transformations attributed to traditional shamans in the literature [Ксенофонтов, 1992, 46-51].

Lavrillier identifies this as "ritual wandering" among the Evenki, something similar to "diagnostic wandering" in western medicine. Here is another example. After the suicide of a relative, one person wanted to make rituals to definitively guide the deceased's soul towards the world of the dead: thus, all risks of disturbing the living would be avoided. The person first asked the closest Orthodox priest, who refused, shocked by such a death. Then this individual went to a young Evenko-Buriat shaman, who did the necessary ritual. He was seen as very strong, able to travel in the lower world: a very difficult task according to past traditional Evenki shamans. This shaman charged for his consultation, something prohibited in traditional Evenki shamanism, but which has become accepted in the practices of new shamanising persons.

Some Evenki who are directly or indirectly involved with such budding shamans think that shamanism, Buddhism, Christianity, Feng Shui, esotericism, Yoga, sound therapy with bells, etc., belong to the same principle of the human-nature relationship: "Only, the idea of nature is differently expressed. There is not such a big difference between addressing one or the other. Just that the shaman is a more powerful mediator between humans and nature". Such arguments have allowed some budding shamans or shamanising persons to associate elements from traditional Evenki shamanism with alien traditions. This initial opening-up towards outside beliefs reminds us partly of the universalising trends of neo-shamanism among other Siberian and Mongolian peoples [Mandelstam Balzer, 1993; Humphrey, 1996; Hamayon 2015; Merli, 2007; Kharitonova, 2006; among others].

\section{Young potential shamans in the 2010s and 2020s}

In several villages and nomadic camps, many narratives discuss potential shamans, those who show the signs of election by shaman spirits but do not know about it. One can sum up the informants' explanations as follows: "Spirits want them to be a shaman, but there is nobody to help them to become a shaman. Shamanism will always exist, it is here, it will elect somebody, and they will be the elected person whether willing or not, with a higher education or not, poor or rich, whether this person be a scientist or a reindeer herder: it will not hinder this election, shamanism will find the necessary person! You cannot do anything against this" [Lavrillier FN 2016].

Lavrillier noted that the Evenki identify elections mostly among young women (nomads or villagers). While behaving mostly normally, in other moments they experience affected mental states, violent crises during which they demonstrate abnormally physical strength, moments of absence (as if they are staring at something/somebody), and very 


\section{Антропология религии / Anthropology of Religion}

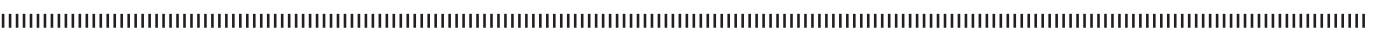

strange behaviours (like walking naked in the forest, screaming for help from invisible entities or discussing and fighting with invisible entities). Only some of them think they are future budding shamans. Their behaviours cause many discussions in villages and nomadic areas. These symptoms remind us of those described by Shirokogoroff [Shirokogoroff, 1935, 264 et passim]. People are very afraid of them: they are torn between recognizing them as psychologically ill and believing in their shamanic future.

Lavrillier has identified several profiles and behaviours in such shamanic elections. In all cases, the individuals concerned and their relatives feel helpless when dealing with these shamanic election issues, a good example of "ritual wandering". 1/ Some of these persons suffer from occasional crises caused by affected mental states (see above) that their acquaintances treat first, unsuccessfully, with western medicines and confinement in psychiatric hospitals. Second, such future budding shamans, helped by friends or relatives, visit neo-shamans among other ethnically related peoples who have accepted neo-shamanism (Buriat, Khamnigan), although not Yakut ones because of historical interethnic tensions. Others try to treat their troubles themselves by testing alien techniques like astrology, numerology, etc. 2/ Other future budding shamans suffer intensively from these shamanic election symptoms and leave towns and villages to spend all their time in the forest with the reindeer. They claim that they are terribly ill in villages or towns. One of them suddenly abandoned everything at thirty years old (job, career, house) to practice a nomadic life in the forest (see above the traditional shamans who cannot bear villages/ towns). Such people say they cannot tolerate the agitation, electronic items, and crowds in villages/towns. They declare they feel each individual, their troubles, thoughts, spirits, and personalities; consequently, they start filling unbearable physical pain. They claim they can treat people with their hands, that they feel the need to treat people when their hands get hotter and provide a strong benevolent energy. Sometimes, such future budding shamans have no direct ancestral link with shamans: they think their symptoms could come from "shamanising elders" with whom they engaged in close knowledge exchange (handicrafts, singing, dancing, etc.). The neo-shamans who help them identify them as future potential shamans who do not understand what is happening. One was identified as a future "white shaman", a future protector of the village: as such, this person must live in the forest to become a shaman. These Tungus-related neo-shamans ordered the future shaman's relatives to make an offering of coloured fabric at a big tree close to the television antenna in the village's surroundings. Followed by most villagers, this gesture initiated a collective ritual and a new offering place (ulganikit). Lavrillier also collected narratives about three young female shamans from Khatystyr who were visiting elders in eastern Siberian villages to amass shamanic knowledge. They told about spirits and strange beings that only they could see or converse with [Lavrillier FN 1990s, 2018, 2019, 2021; see also Zabiyako et al., 2012, 249].

To conclude our Evenki/Even cases studies in Yakutia, Amur, and Kamchatka, Lavrillier argues that shamanism is seen as a complex linked to spirits that has survived the lack of shamans, historical events and policies, and cultural changes, almost as if it is everlasting and embedded in the natural environment. It is also independent from the concept of "person" (i.e. as defining a social and hierarchical position [Mauss, 1991, 101-115, 340-345]), and lifestyle. It derives not from humans, but from the natural environment.

Shamanising persons who are unable to become shamans, in contrast to traditional shamans, act malevolently towards people. Such individuals include potential shamans defeated by traditional shamans, psychologically ill persons unable to become shamans, people able to act through simple thoughts, and failed shamans.

Furthermore, the relatives of new shamanising persons play an important role in helping an individual to become a shaman. This could be a remanent of the past, when each clan had its own shaman.

Finally, this analysis argues that as with Evenki shamans both past and present, the status of current "shamanising persons" (healer, diviner, preacher, prophet, pseudo-shaman, etc.) is not confirmed by auto-proclamation, but is granted only if the results of the care/rituals are deemed satisfactory by the community. Likewise, this status is never granted for life: it can be removed if the ritual specialist loses effectiveness. As noted by Lavrillier, this was also the case for Vasilev, who was disregarded at several points in his 


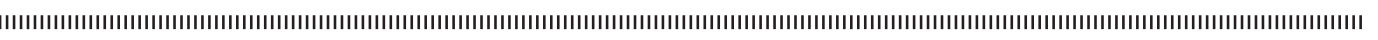

life. This is a big difference with western-influenced neo-shamans and the case studies offered by T. Sem below.

The Evenki and Nanai of Novorossiysk and Khabarovsk Shamanising persons gathering spirits through figurines

Sem was contacted in 2020 by Alexey Vladimirovich Goncharov, an EvenkoRussian born in 1958: he attested that his grandfather was a great shaman. This was all he knew about him: he had no idea about where he lived or his ultimate fate. Goncharov was born in Michurinsk (Tambolskii region) and now lives in Novorossiysk. In dreams, he sees shamanic defender spirits and helper spirits. Therefore, he became interested in the scientific literature on shamanism as a means for him to understand his state. He thus consulted Sem's books: The Shamanism of the Evenki Based on the Materials of the Russian Ethnographic Museum [Sem, 2017], The Tungus' Worldview: The Pantheon [Sem, 2015], and The Shamanism of Siberian Peoples [Sem, 2011]. The latter is an essay on Tungus-Manchu shamanism (including the Nanai of the Amur River). It analyses shamans' attributes, the features of helper spirits and their figurines, and their role in the formation of a shaman's personality. Goncharov, through his numerous travels in Russia as a lawyer (he is now in the second year of his retirement), met many people and was interested in shamans and their descendants. He did not find among the Evenki active shamans or their descendants, who have shamanic attributes for sale. Then he learned about the descendants of the traditional Nanai shaman Makar Samar (Nergen village, Khabarovskii krai) and the spirit representations (seven) that remained from this shaman and the persons he treated. To his relative Ekaterina Samar, Samar was a medium-level shaman who practised during and after the Second World War. Goncharov sought to gain helper spirits through the acquisition of figurines consecrated by this shaman during rituals.

To Sem's question whether he collects spirits for himself, Goncharov answered positively. Moreover, in dreams the spirits first appear in female form and are then materialised through visions: they became his defenders or helpers. Note this shaman election was performed by the opposite gender, a pattern first remarked upon among the Nanai by Sternberg [Sternberg, 1933, 463-464].

Sem asked Goncharov why he does not use the spirits of his Evenki people, but Nanai spirit figurines. He answered that the Evenki and Nanai are peoples related by language and a common shamanism. As a specialist of Evenki, Nanai, and Siberian Tungus shamanism, Sem does distinguish between the cultural features of Evenki and Nanai shamanisms, but also asserts a certain commonality of Tungus shamanism on both Siberian and global levels. This case study shows that the descendant of an Evenki shaman (Goncharov) looks at the world more broadly than ethnological science. For him, the very idea of acquiring helper and defender spirits is important in order to explain dreams and visions during an altered state of consciousness. This is a common attitude of many "ekstrasens" (people with extrasensory perception/psychic powers), be they initiated or not in neo-shamanism. Goncharov did not pass a special initiation because, as he said, there was nobody capable of doing this. This contrasts with some current neo-shamans and shamanising persons. Goncharov obtained by himself his defender and helper spirits through visions in dreams; they give him knowledge about himself and surrounding "reality".

Self-discovered knowledge and self-development are the main psychological tools of Goncharov, this modern ekstrasens and descendant of an Evenki shaman. He tells the following about his dreams:

"When I receive a seven, I put it to the test for the night with me. Like this. If he came to me and did not show himself in any way, I think it is necessary to sell him (I sell the ones that do not show themselves). Once my friend spent the night at my house and it turns out I left the house, and the seven remained on the bedspread. My friend, for some reason, decided to shake out the bedspread, but he did not notice how seven was also shook out from the balcony. I came home and started looking for the seven and then I understood it was somewhere downstairs under the balcony. I went looking for it and found it. I apologized to him for this incident and definitely decided to sell it, since to me it was a sign that he wanted to leave me. This night I had a very clear dream. I was in a room and a boy about four years old was sitting on the bed and spoke in a strange way - his speech was incoherent and it was as if his legs and arms were broken, he was moving strangely 


\section{Антропология религии / Anthropology of Religion}

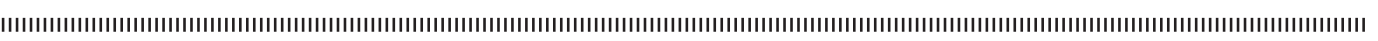

like a spider. I was afraid of him and tried to keep him away from me. And then two old women entered the door: one was 80 years old, the other 70 and they said, 'Are you giving away the dog?' I answered, 'I have no dog'. Then, from behind the old women, a big white dog appeared. The old women said, 'Who should we pick up then?'I said, 'Take this child, he scares me'. And then one grandmother took him by the collar and threw him like a puppy from the balcony. Then we all went out: the old women disappeared and I saw the corpse of the child and I felt sorry for him since because of me he was thrown like that. I passed on and in front of me was a young man of about 20 years old, 2.5 meters tall. He leant over to me and said, 'Do you recognized me?' I replied, 'You are the child whom the grandmothers threw from the balcony'. He smiled and said, 'Thank you for not leaving me'. And then I woke up in a cold sweat. So, after this dream, I decided to keep this seven. As if it was necessary to first lose this seven Edzhehe and then find it. I understand it sounds like nonsense, but still. Since then, it has been hanging around my neck".

Finding helper spirits in this way is Goncharov's main task. He sent to Sem the photos of the seven he received from the shaman Samar's relatives and from the people Samar cured (they no longer needed the idols). Sem was able to recognise the seven in these pictures in the collections of the Russian Ethnographic Museum: they are typical of Nanai shamanism. In shaman practice, the representation of the main shamanic defender and helper spirits follow canons of representation preserved until the twenty-first century.

Goncharov's collection of figurines includes 14 seven, cast from different metals: silver, bronze, and iron. Three groups stand out:

1) Five seven made of silver, which include Edzhehe (the ancestor spirit, the heavenly mediator from the supreme deity Boa, used as a personal protecting spirit), two Aiami (the main defender of shamans, among whom could be Maidia Mama, a female deity of fertility, and Erhii mergen, a male deity of fertility), Kalgama (the spirit of the forests, mountains, and rivers), and Dzhulin (an ancestor spirit and household defender) (Illus. 2).

2) Three bronze figurines with rhombic heads, rectangular bodies, and short legs. The ribs are marked on the body, a symbol of the shaman's transition to the state of the ancestor's spirit. These figurines were made by the shaman Samar for consecration to one woman and are called Edzhehe-ancestors, personal helper spirits. This group also includes two iron representations of Edzhehe, one with two faces, the other with a rounded torso (Illus. 3).

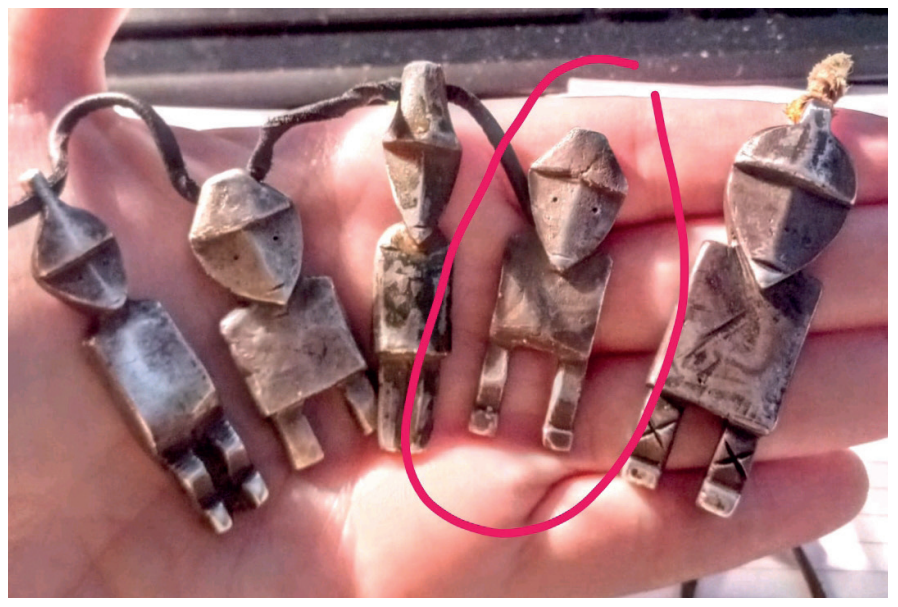

Illus. 2. First group spirits: $1-$ Edzhehe;

2, 4-Aiami; 3-Kalgama; 5 -Dzhulin. From the traditional Nanai shaman Makar Samar (mid-twentieth century). Picture: A.V. Goncharov.

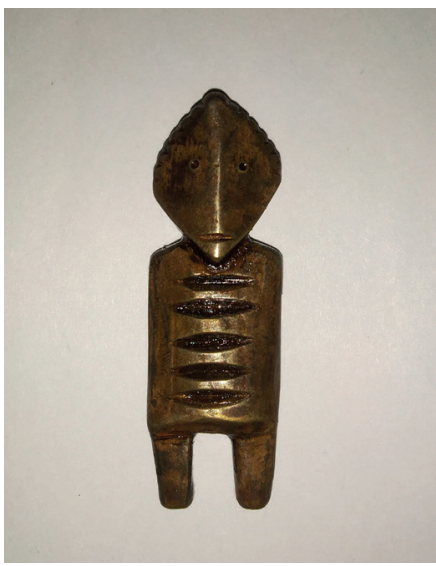

Illus. 3. Second group spirits Edzhehe. From the traditional Nanai shaman Makar Samar (mid-twentieth century). Picture: A.V. Goncharov.

3) Iron figurines with a very interesting iconography reminiscent of ancient wooden figures and similar to those in A.V. Smolyak's book The Shaman: Personality, Functions, and Worldview (the Peoples of the Lower Amur) [Smolyak, 1991, 95, 128-129]. Three figurines represent ancestral spirits in the form of the master of the household and the domestic fire (Illus. 4). 


\section{Антропология религии / Anthropology of Religion}

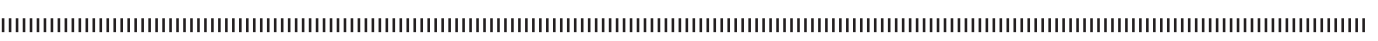

A Dzhulin has a typical iconography, with a rhombic head, a square body, and short legs. One Dzhulin has breasts on his chest. Dzhulin figurines were in every Nanai house and could be male and female ancestors of the clan [Sem, 2003, 172-174]. Within this group, Goncharov had a seven with the figure of Buchu, a winged, bird-headed, one-legged figurine with a rectangular body: this depicts the main shamanic mediator between the worlds of the universe [Lopatin, 1922, 222-224; Chadaeva, 1986, 56-64]. Buchu is represented as a bird-snake, a very ancient representation of shamanic initiation [Sem, 2015, 357]. This

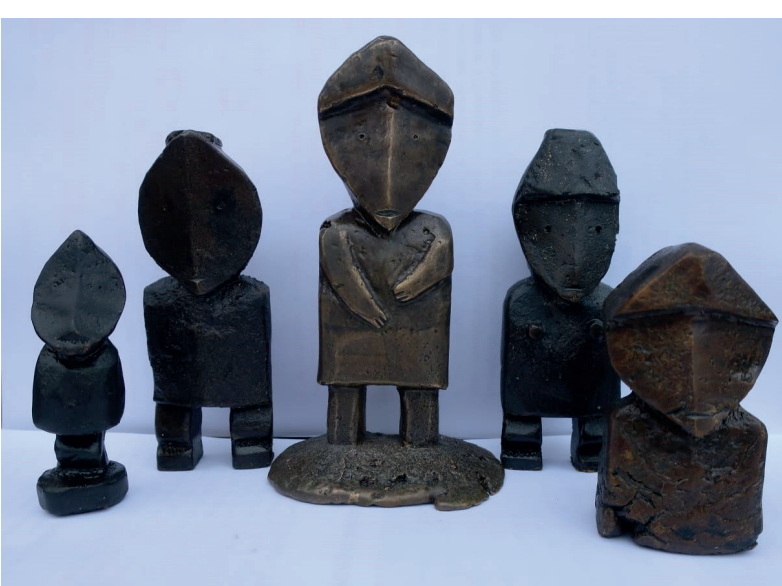

Illus. 4. Third group spirits: 1, 3, 5-Dzhulin; 2 - Buchu; 4 -Podia. From the traditional Nanai shaman Makar Samar (mid-twentieth century). Picture: A.V. Goncharov. Dzhulin was offered to Goncharov

by Samar's relatives. The figurine was used in extreme cases of disease. There is another important figure: the seven Podia with a rhombic head and a square body without arms and legs. This depicts the spirit of fire, protecting fishing and life. The fire spirit was one of the most important master spirits for the Nanai and Evenki.

Let us note that not only do the descendants of Siberian shamans turn to shamanism: Russians do so too. Goncharov mentioned a Russian journalist from Moscow working for the government: she studied Siberian shamanism and has spirit figurines that she feeds and takes care of, just like the types of shamanising persons who worship the spirit figurines of shamans to gain shamanic knowledge. Thus, ideas of shamanism have deeply penetrated the consciousness of townspeople and have spread. The urban neo-shamans are consecrated or simply initiated into shamanic knowledge. Among current researchers of Siberian peoples, some are also deeply imbued with this faith and consider themselves shamanists: the recently deceased A. A. Burykin, for instance. A famous doctor of philology and the historical sciences, he authored the book Shamans: Those Whom the Spirits Serve [Burykin, 2007].

Today, the Nanai medical doctor Ekaterina Dmitrievna Samar [Samar, 2003], from a shamanic family, has collected unique material about Nanai beliefs and shamanism in the book Under the Shadow of the Family Tree. She also studied the shamanism of her ancestors in the Samar clan. She belongs to a group of shamanising persons who have not undergone consecration, but who collect spirits through knowledge gained from books. In her book's first volume, she presents the shamanic spirits, traditions, and modern understandings. Thus, among the shamanic helper spirits of the Samar shaman clan she describes the following: Aiami, Edzhehe, Dzhulin, Podia, Gorodo, Buchu, Magliandi-Mama, Buchile, and Ado seveni (Na Duenteni and Mue Duenteni), among others. She writes that the main shaman spirits were Aiami. The seven Edzhehe (a seven given by the sky) could be a couple, male and female. The spirit Dzhulin played a crucial role in the household: the Samar had only female Dzhulin, while in other clans they were female and male. The Nanai asked the Dzhulin for successful trips, good luck in important tasks, and defence against malevolent spirits. Shamans asked the seven Podia for success in everyday activities and fishing/hunting. Podia belong to the shamanic complex of Ado-seveni, twins of the Na Duenteni group of the earth bear. The spirit of the wind, Buchu, is the main assistant of the shaman; it belongs to the Dzhulin spirit group and to the Gorodo mountain spirits. All these spirit figurines were kept in the family of Ksenia Digor-Samar, who is not a shaman.

Along with wooden figurines, the Samars also owned metal ones. The most interesting was a bunch of silver circles with a female figurine (the Magliandi-Mama) and the personal protector spirit Edzhehe inside, made of lead. Magliandia-Mama was interpreted 
as the mistress of the universe, a symbol of the "pre-physical state of the universe", as Samar writes. She probably means the mistress of chaos, who was also the mistress of animals, since there is a representation of two snow leopards on both sides of the circle [Samar, 2003, 18, 30, 47, 52, 64, 157-161]. A similar spiritual entity is found among the Evenki: Bugady Enin, Enieke Bugady, or Eniekan Buga, the master of the world and people and the mistress of sacred mountains and the souls of plants, animals, and people. It is to this spirit that the shaman flies during the main New Year ritual [Mazin, 1984, 11-13, 91; Anisimov, 1958, 29] (see also above).

Thus, these two examples of Tungus-Manchu shamanising persons (Evenki and Nanai) with shamans in their families testify to their involvement in collecting spirits for the purpose of self-discovering knowledge. The Evenki Goncharov is actively seeking an explanation for his dreams and meetings with the helper spirits: he purposefully acquires them through metallic figurines from the Nanai shaman Samar. The Nanai neophyte E. Samar, a practitioner, collects information about shamanic helper spirits and writes books with the aim of preserving shamanic traditions: she is looking for an explanation of their sacredness. Neither individual helps or heals people.

\section{Conclusion}

Sem's case studies contrast with those of Lavrillier. Indeed, the Evenki and Even of Yakutia, the Amur region, and Kamchatka no longer possess items given by shamans during a ritual (if they do so, it is very rare and kept entirely secret). Such items (figurines of spirits and birds, stones, hairs from a wolf tail, etc.) must not be shown or given away, let alone sold to outsiders. They must be hidden forever in the taiga after death: touching them brings the risk of terrible reprisals from the spirits [Lavrillier FN 1994-2021].

Several common collective spiritual representations and practices have emerged: ritual wandering to become a traditional shaman or shamanising person (as no traditional shamans now exist for teaching: nor are there any elders able to master shamanic attributes); the determining criterion of being the descendent of a shaman in order to become a shamanising person; the appearance of money in ritual practices (buying figurines or the services of shamanising persons); the influence of ethnographic literature in the reconstitution of ritual practices; the use of new technologies (phones, the internet) in rituals; the appeal to neo-shamans belonging only to ethnically related Tungus peoples (Evenki, Buriat, Khamnigan, Nanai); and the rejection of neo-shamans from outside the Tungus cultural realm.

\section{Acknowledgments}

Sem's study was funded by the RFBR and CNRS project N ${ }^{\circ} 21-59-15002$, as were the translation costs. Lavrillier's field studies were funded by the French Polar Institute, the Louis Dumont Foundation, the Russian Academy of Science, the Max Planck Institute, and the Fyssen Foundation.

\section{List of abbreviations}

Lavrillier/Sem FN + year = Lavrillier's/Sem's field notes from the year in question.

\section{Бибпиографический список}

1. Анисимов, А.Ф. Религия эвенков в историко-генетическом изучении и проблем происхождения первобытных веровании / А.Ф. Анисимов. - Москва/Ленинград: Издательство Академии Наук СССР, 1958. - 235 с.

2. Бурыкин, А.А. Шаманы. Те, кому служат духи / А.А. Бурыкин. - СПб.: Азбука-классика, Петербургское востоковедение, 2007. - 287 с.

3. Василевич, Г.М. Древние охотничьи оленеводческие обряды эвенков / Г.М. Василевич // Сборник Музея антропологии и этнографии. - 1957. - № 1 (XVII). - C. 151-185.

4. Василевич, Г.М. Некоторые данные по охотничьим обрядам и представлениям у тунгусов / Г.М. Василевич // Этнография. - 1930. - № II (3). - С. 57-67.

5. Забияко, А.П. Эвенки Приамурья: оленная тропа истории и культуры / А.П. Забияко [и др.]. - Благовещенск: АмГУ, 2012. - 384 с. 


\section{Антропология религии / Anthropology of Religion}

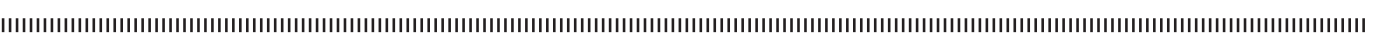

6. Ксенофонтов, Г.В. Шаманизм: избранные труды / Г.В. Ксенофонтов. - Якутск: Фирма «Север-Юг», 1992. - 315 с.

7. Кэптукэ, Г.И. Эпические традиции в эвенкийском фольклоре (очерки) / Г.И. Кэптукэ. Якутск: Северовед, 1996. - 134 с.

8. Лавриллье, А. Песни, танцы и слова - основы ритуальной игры эвенков. Систематический, терминологический и семантический анализ 28 ритуальных песен / А. Лавриллье // Традиционная культура Востока Азии. - 2007b. - Вып. 5. - С. 289-299.

9. Лавриллье, А. Эвенкийская «игра» эви- /икэ-: между игрой и ритуальным / А. Лавриллье // Религиоведение. - 2007а. - № 1. - С. 3-8.

10. Лопатин, И.А. Гольды амурские, уссурийские и сунгарийские / И.А. Лопатин. Владивосток, 1922. - 370 с.

11. Мазин, А.И. Традиционные верования и обряды эвенков-орочонов / А.И. Мазин. Новосибирск: Наука, 1984. - 200 с.

12. Самар, Е.Д. Под сенью родового древа / Е.Д. Самар. - Хабаровск: Хабаровское книжное издательство, 2003. - 211 с.

13. Сем, Т.Ю Категории шаманов у тунгусов Восточной Сибири и Дальнего Востока и проблемы белого шаманства Евразии / Т.Ю. Сем // Материалы третьих Санкт-Петербургских этнографических чтений. - СПб., 2004. - С. 343-249.

14. Сем, Т.Ю. Картина мира тунгусов: пантеон (семантика образов и этнокультурные связи). Историко-этнографические связи / Т.Ю. Сем. - СПб.: Филфак СПБГУ, 2015. - 640 с.

15. Сем, Т.Ю. Шаманизм народов Сибири. Этнографические материалы XVIII-XX вв.: хрестоматия в 2 т. Изд. 2-е, испр. и доп. / Т.Ю. Сем. - СПб.: Филологический факультет СПбГУ; «Нестор-история», 2011. - Т. I-II. - 482 с., 492 с.

16. Сем, Т.Ю. Шаманизм эвенков по материалам Российского этнографического музея: изд. 2, исправленное и дополненное / Т.Ю. Сем. - Издательский центр «Гуманитарная академия», 2017. $-302 \mathrm{c}$.

17. Смоляк, А.В. Шаман: личность, функции, мировоззрение (народы Нижнего Амура) / А.В. Смоляк. - Москва: Наука, 1991. - 279 с.

18. Токарев, С.А. Ранние формы религии и их развитие / С.А. Токарев. - Москва: Наука, 1964. -399 c.

19. Туголуков, В.А. Полевые исследования в Северном Приамурье. Полевые исследования Института этнографии / В.А. Туголуков. - Москва: Наука, 1975. - № 2. - С. 36-44.

20. Харитонова, В.И. Феникс из пепла? Сибирский шаманизм на рубеже тысячелетий В.И. Харитонова. - Москва: Наука, 2006. - 372 с.

21. Чадаева, А.Я. Национальная игрушка: Очерки о древ. предках дет. игрушки народностей Чукотки и Приамурья / А.Я. Чадаева. - Хабаровск: Хабаровское книжное издательство, 1986. -96 c.

22. Штернберг, Л.Я. Гиляки, орочи, гольды, негидальцы, айны / Л.Я. Штернберг. Хабаровск: Дальгиз, 1933. - 740 с.

23. Bulgakova, T.D. Nanai Shamanic Culture in Indigenous Discourse / T.D. Bulgakova. - Fürstenberg: Kulturstiftung Sibirien, Studies in Social and Cultural Anthropology, 2013. - $261 \mathrm{p}$.

24. Hamayon, R. Introduction à Chamanismes. Réalité autochtones, réinventions occidentales [Introduction to Shamanisms. Indigenous Reality, Western Reinventions] / R. Hamayon. - Diogène, Paris, PUF no. Chamanismes, 2003. - P. 7-54.

25. Hamayon, R. Le chamanisme. Fondements et pratiques d'une forme religieuse d'hier et d'aujourd'hui / R. Hamayon. - Paris: Eyrolles, 2015. - 180 p.

26. Humphrey, C. Shamans and Elders: Experience, Knowledge, and Power Among the Daur Mongols / C. Humphrey, U. Onon. - Oxford: Clarendon Press, 1996. - 396 p.

27. Lavrillier, A. "Spirit-Charged" Animals in Siberia. In Shaman in Rainforest and Tundra: Personhood in the Shamanic Ecologies of Contemporary Amazonia and Siberia / A. Lavrillier / Ed. by V. Grotti, O. Ulturgasheva, and M. Brightman. - Oxford: Berghahn Books, 2012. - P. 113-129. 28. Lavrillier, A. "Spirit-Charged" Humans in Siberia: Interrelations between the Notions of the Individual ("Spirit Charge" and "Active Imprint") and (Ritual) Action / A. Lavrillier // Arctic Anthropology. - 2020. - Vol. 57. - No. 1. - P. 72-98.

29. Lavrillier, A. Even Tales of Dar'ia Mikhailovna Osenina. Evenskie nimkany Dar'i Mikhajlovna Osenina / A. Lavrillier, D. Matic. - Fürstenberg: Kulturstiftung Sibirien, 2013. - 158 p.

30. Lavrillier, A. De l'oubli à la reconstruction d'un rituel collectif. L'Ikènipkè des Évenks [From Forgetting to the Reconstruction of a Collective Ritual. The Ikènipkè of the Evenki] / A. Lavrillier // Слово. - 2003. - No. 28-29. - Р. 169-191.

31. Lavrillier, A. Evenki: Ritual Songs of the Nomadic Taiga People [Booklet, Translated Songs, CD 3015792] / A. Lavrillier, H. Lecomte. - Paris: Buda Records, 2002. - 35 p.

32. Lavrillier, A. Nomadism e et adaptations sédentaires chez les Évenk de Sibérie postsoviétique: "Jouer." Pour vivre avec et sans chamanes. [Nomadism and Adaptations to a Sedentary Lifestyle 


\section{Антропология религии / Anthropology of Religion}

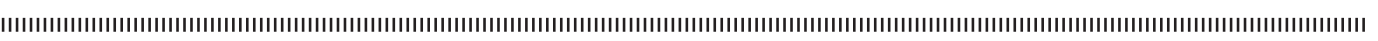

among the Evenki of Post-Soviet Siberia: "Playing" to Live with and without Shamans. PhD thesis in Anthropology] / A. Lavrillier. - Department for Studies of Religions, École Pratique des Hautes Etudes of Paris, Paris, 2005. - 2 vols. -559 p. and 237 p.

33. Lavrillier, A. Les formes de chamanisme en Sibérie chez les Evenks et les Iakoutes (Iakoutie et région de l'Amour) 2003 [The Forms of Shamanism in Siberia among the Evenks and the Yakuts (Yakutia and the Amur Region)] [Электронный pecypc] / A. Lavrillier // 1e Congrès du Réseau Asie (MSH), (septembre 2003), Thème VI "Politique et religion", atelier "Chamanisme et gestion des maux", [en ligne]. - URL: www.reseau-asie.com (дата обращения 10.03.2021).

34. Le Berre-Semenov, M. Renaissantismes et renaissance des peuples du nord. Evolution de la question autochtone en République sakha (Yakoutie) dans le contexte des mutations postsoviétiques [Revivalism and Rebirth of the Peoples of the North. The Evolution of the Indigenous Question in the Sakha Republic (Yakutia) in the Context Post-Soviet Mutations] / M. Le BerreSemenov. - Paris-Louvin: éditions Peeters, 2008. - 386 p.

35. Lecomte, H. Les esprits écoutent. Musiques des peuples autochtones de Sibérie [The Spirits are Listening. The Music of the Indigenous Peoples of Siberia] / H. Lecomte. - Paris: Sampzon, Éditions Delatour France, 2012. - 191 p.

36. Mandelstam Balzer, M. Two Urban Shamans: Unmasking Leadership in Fin-de-Soviet Siberia / M. Mandelstam Balzer // Perilous States: Conversations on Culture, Politics, and Nation. - Chicago: University of Chicago Press. George E. Marcus, 1993. - P. 131-164.

37. Mauss, M. Sociologie et anthropologie [Sociology and Anthropology] / M. Mauss. - Paris: Presse Univeritaire de France, 1991. - 482 p.

38. Merli, L. Chamanisme mongol versus néo-chamanisme occidental: Étude des processus interculturels de transmission, d'apprentissage et d'exportation des savoirs et des représentations [Mongolian Shamanism versus Western Neo-Shamanism: A Study of the Intercultural Processes of Transmission, Learning, and Export of Knowledge and Representations] / L. Merli // Annales de la Fondation Fyssen. - 2007. - No. 22. - P. 99-111.

39. Rojo, M. Adaptation des rites "traditionnels" chez les Touvas de Kyzyl de la période soviétique à l'urbanisation [The Adaptation of "Traditional" Rites among the Kyzyl Tuvas of the Soviet Period to Urbanization] [Электронный ресурс] / M. Rojo, R.M. Chondan, S.S. Chondan, A. Lavrillier // Études mongoles et sibériennes, centrasiatiques et tibétaines, 47 / 2016. - URL: http://emscat. revues.org/2856 (дата обращения 15.03.2021).

40. Shirokogoroff, S.M. The Psychomental Complex of the Tungus / S.M. Shirokogoroff. London: Kegan Paul, Trench, Trubner and Co, 1935. - T. 1. - 240 p.; T. 2. -469 p.

41. Stepanoff, C. Chamanisme, ritual et cognition chez les Touvas (Sibérie du Sud) [Shamanism, Ritual, and Cognition among the Tuva (Southern Siberia)] / C. Stepanoff. - Paris: MSH. 2002. $406 \mathrm{p}$.

42. Varlamov, A. Electronic Devices for Safeguarding Indigenous Languages and Cultures (Eastern Siberia) / A. Varlamov, K. Galina, A. Lavrillier / Ed. By Timo Koivurova, Else Grete Broderstad, Dorothée Cambou, Dalee Dorough, and Florian Stammler. - Routledge Handbook of Indigenous Peoples in the Arctic, London and NY: Routledge, 2020. - P. 58-75.

43. Vaté, V. Kilvêi: The Chukchi Spring Festival in Urban and Rural Contexts / V. Vaté // Rebuilding Identities: Pathways to Reform in Post-Soviet Siberia / Ed. by Erich Kasten. - Berlin: Dietrich Reimer Verlag, 2005. - P. 39-62.

44. Vitebsky, P. Siberia / P. Vitebsky, A. Alexeev // Annual Review of Anthropology. - 2015. No. 44. - P. 439-455.

Текст поступил в редакиию 22.03.2021.

Принят к публикачии 02.08.2021.

Опубликован 28.09.2021.

\footnotetext{
${ }^{1}$ On anti-shaman repression among the Nanai, see [Bulgakova, 2013, 198 et passim].

${ }^{2}$ In the anthropological works of the 1990 s, such rituals were sometimes qualified as "revivalist" or "from [a] revival movement" [Keptuke 1996, 26; Le Berre-Semenov 2008, 209-333; Vaté, 2005; among others]. ${ }_{3}^{3}$ The latter are said to be seats for the spirits during shamanic séances [Mazin, 1984].

${ }^{4}$ The Khamnigan people result from Buriat and Evenki intermarriages, while most Buriat have Evenki blood according to Evenki and Buriat representations.

${ }^{5}$ Spraying milk on the grass contradicts Evenki prescriptions, according to which reindeer milk must not be thrown on the ground, but either drunk or be given to a fire or river.

${ }^{6}$ The ability attributed to (full) moon light to instil a spirit within an item was common among the Evenki nomads between the 1990s and 2010s. They, for instance, forbade their children from leaving any toys outside at night in the (full) moon light, fearing that a spirit could be uploaded into the toy [Lavrillier, 2005]

${ }^{7}$ Note the same avoidance of overly intensive contact with the spirits among the Nanai [Bulgakova, 2013, 163].
} 


\section{Антропология религии / Anthropology of Religion}

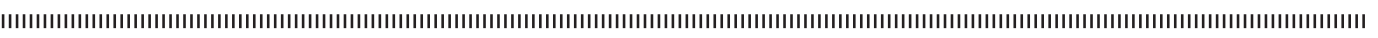

\section{References}

1. Anisimov A.F. Religiia evenkov v istoriko-geneticheskom izuchenii i problem proiskhozhdeniia pervobytnykh verovanii [The Religion of the Evenki in a Historical-Genetic Study on the Issues of the Origin of the First Beliefs]. Moscow/Leningrad: Izdatel'stvo Akademii Nauk SSSR., 1958, 235 p. (in Russian).

2. Bulgakova T.D. Nanai Shamanic Culture in Indigenous Discourse. Fürstenberg: Kulturstiftung Sibirien, Studies in Social and Cultural Anthropology. 2013, 261 p.

3. Burykin A.A. Shamany. Te, komu sluzhat dukhi [Shamans. Those Whom the Spirits Serve]. St. Petersburg: Azbuka-klassika, Peterburgskoie vostokovedeniie, 2007, 287 p. (in Russian).

4. Chadaeva A.Ya. Natsional'naia igrushka. Ocherki o drevnikh predkakh detskoi igrushki narodnostei Chukotki i Priamur'ia [The National Toy. Essays on the Ancient Predecessors of Children's Toys of the Peoples of Chukotka and the Amur Region] Khabarovsk: Khabarovskoie knizhnoie izdatel'stvo, 1986, 96 p. (in Russian).

5. Hamayon R. Introduction to Shamanisms. Indigenous Reality, Western Reinventions [Introduction à Chamanismes. Réalité autochtones, réinventions occidentales]. Diogène. Paris, PUF no. Chamanismes, 2003, pp. 7-54 (in French).

6. Hamayon R. Shamanism. Foundations and practices of a religious form of yesterday and today [Le chamanisme. Fondements et pratiques d'une forme religieuse d'hier et d'aujourd'hui]. Paris: Eyrolles, 2015, 180 p. (in French).

7. Humphrey C., Onon U. Shamans and Elders: Experience, Knowledge, and Power Among the Daur Mongols. Oxford: Clarendon Press, 1996, 396 p.

8. Keptuke GI. Epicheskie traditsii v evenkiiskom fol'klore (ocherki) [Epic Traditions in Evenki Oral Literature]. Yakutsk: Severoved', 1996, 134 p. (in Russian).

9. Kharitonova V.I. Feniks iz pepla? Sibirskii shamanizm na rubezhe tysiacheletii [A Phoenix from the Ashes? Siberian Shamanism at the Turn of the Millennium]. Moscow: Nauka, 2006, 372 p. (in Russian). 10. Ksenofontov G.V. Šamanizm: izbrannye trudy [Shamanism: Selected Works]. Yakutsk: Firma "SeverJug”, 1992, 315 p. (in Russian).

11. Lavrillier A. Religiovedenie [Study of Religion]. 2007a, no. 1, pp. 3-8 (in Russian).

12. Lavrillier A. Tradicionnaja kul'tura Vostoka Azii [Traditional Culture of the East of Asia]. Blagoveshshensk, Sibirskoe Otdelenie Rossijkoj Akademii Nauk, AMGU, 2007b, vol. 5, pp. 289-299 (in Russian). 13. Lavrillier A. "Spirit-Charged" Animals in Siberia in Shaman in Rainforest and Tundra: Personhood in the Shamanic Ecologies of Contemporary Amazonia and Siberia. V. Grotti, O. Ulturgasheva, and M. Brightman, eds. Oxford: Berghahn Books. 2012, pp. 113-129.

14. Lavrillier A. "Spirit-Charged" Humans in Siberia: Interrelations between the Notions of the Individual ("Spirit Charge" and "Active Imprint") and (Ritual) Action. Arctic Anthropology, 2020, vol. 57, no. 1, pp. 72-98.

15. Lavrillier A., Matic' D. Even Tales of Dar'ia Mikhailovna Osenina. Evenskie nimkany Dar'i Mikhajlovna Osenina. Fürstenberg: Kulturstiftung Sibirien, 2013, 158 p.

16. Lavrillier A. De l'oubli à la reconstruction d'un rituel collectif. L'Ikènipkè des Évenks [From Forgetting to the Reconstruction of a Collective Ritual. The Ikènipkè of the Evenki]. Slovo. 2003, no. 28-29, pp. 169-191 (in French).

17. Lavrillier A. Nomadisme et adaptations sédentaires chez les Évenk de Sibérie postsoviétique: “Jouer." Pour vivre avec et sans chamanes. [Nomadism and Adaptations to a Sedentary Lifestyle among the Evenki of Post-Soviet Siberia: "Playing" to Live with and without Shamans. PhD thesis in Anthropology]. Department for Studies of Religions, École Pratique des Hautes Etudes of Paris, Paris. 2005, 2 vols. 559 p. and 237 p. (in French).

18. Lavrillier A., Lecomte H. Evenki: Ritual Songs of the Nomadic Taiga People [Booklet, Translated Songs, CD 3015792]. Paris: Buda Records, 2002, 35 p.

19. Lavrillier A. Les formes de chamanisme en Sibérie chez les Evenks et les Iakoutes (Iakoutie et région de l'Amour) 2003 [The Forms of Shamanism in Siberia among the Evenks and the Yakuts (Yakutia and the Amur Region)] in $1^{e}$ Congrès du Réseau Asie (MSH), (septembre 2003), Thème VI "Politique et religion", atelier "Chamanisme et gestion des maux", [en ligne]. Available at: www.reseau-asie.com (accessed on March 10, 2021) (in French).

20. Le Berre-Semenov M. Renaissantismes et renaissance des peuples du nord. Evolution de la question autochtone en République sakha (Yakoutie) dans le contexte des mutations post-soviétiques [Revivalism and Rebirth of the Peoples of the North. The Evolution of the Indigenous Question in the Sakha Republic (Yakutia) in the Context of Post-Soviet Mutations]. Paris-Louvin: éditions Peeters, 2008, 386 p. (in French).

21. Lecomte H. Les esprits écoutent. Musiques des peuples autochtones de Sibérie [The Spirits are Listening. The Music of the Indigenous Peoples of Siberia]. Paris: Sampzon, Éditions Delatour France, 2012, 191 p. (in French).

22. Lopatin I.A. Gol'dy amurskiie, ussuriyskiie i sungariyskiie [The Amur, Ussuri, and Sungari Gold]. Vladivostok, 1922, 370 p. (in Russian).

23. Mandelstam Balzer M. Two Urban Shamans: Unmasking Leadership in Fin-de-Soviet Siberia. In Perilous States: Conversations on Culture, Politics, and Nation. Chicago: University of Chicago Press, 1993, pp. 131-164.

24. Mauss M. Sociologie et anthropologie [Sociology and Anthropology]. Paris: Presse Univeritaire de France, 1991, 482 p. (in French). 


\section{Антропология религии / Anthropology of Religion}

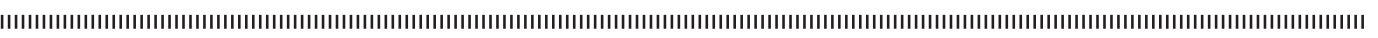

25. Mazin A. I. Traditsionnye verovaniia i obriady evenkovorochonov [The Traditional Beliefs and Rituals of the Orochen-Evenki]. Novosibirsk: Nauka, 1984, 200 p. (in Russian).

26. Merli L. Chamanisme mongol versus néo-chamanisme occidental: Étude des processus interculturels de transmission, d'apprentissage et d'exportation des savoirs et des représentations [Mongolian Shamanism versus Western Neo-Shamanism: A Study of the Intercultural Processes of Transmission, Learning, and Export of Knowledge and Representations]. Annales de la Fondation Fyssen, 2007, no. 22, pp. 99-111 (in French).

27. Rojo M., Chondan R.M., Chondan S.S., Lavrillier A. Adaptation des rites "traditionnels" chez les Touvas de Kyzyl de la période soviétique à l'urbanisation [The Adaptation of "Traditional" Rites among the Kyzyl Tuvas of the Soviet Period to Urbanization]. Etudes mongoles et sibériennes, centrasiatiques et tibétaines, 2016, no. 47. Available at: http://emscat.revues.org/2856 (accessed on March 15, 2021) (in French).

28. Samar E.D. Pod sen'yu Rodovogo dreva [Under the Shadow of the Family Tree]. Khabarovsk: Khabarovskoie Knizhnoie izdatel'stvo, 2003, 211 p. (in Russian).

29. Sem T.Yu. Shamanizm narodov Sibiri. Etnograficheskiie materialy 18th-20th centuries: Khrestomatiia $v$ dvukh tomakh [The Shamanism of Siberian Peoples. Ethnographic Materials from the EighteenthTwentieth Centuries in Two Volumes]. St. Petersburg: St. Petersburg State University Faculty of Philology, 2011, vols. 1-2, 482 p., 492 p. (in Russian).

30. Sem T.Yu. Kartina mira tungusov: panteon. (semantika obrazov i etnokul 'turnyie sviazi). Istoriko-etnograficheskie ocherki [A Picture of the World of the Tungus: The Pantheon. (Semantics of Representations and Ethnocultural Ties). Historical and Ethnographic Descriptions]. Essays. St. Petersburg: Filfak SPBGU, 2015, 640 p. (in Russian).

31. Sem T.Yu. Shamanizm evenkov po materialam Rossiiskogo etnograficheskogo muzeia [The Shamanism of the Evenki Based on the Materials of the Russian Ethnographic Museum]. St. Petersburg: Izdatel'skiy Tsentr "Gumanitarnaia Akademiia", 2017, 302 p. (in Russian).

32. Sem T.Yu. Ietnograficheskii istochnik. Materialy Tret'ikh Sankt-Peterburgskikh Etnograficheskikh chtenii [Ethnographic Source. Proc. Of the $3^{\text {rd }}$ St. Petersburg Ethnographic Readings]. St. Petersburg, 2004, pp. 249-343 (in Russian).

33. Shirokogoroff S.M. The Psychomental Complex of the Tungus. London: Kegan Paul, Trench, Trubner and Co. 1935, vol. 1, 240 p.; vol. 2, 469 p.

34. Sternberg L.Ya. Giliaki, orochi, gol'dy, negidal'tsy, ainy [Gilyaks, Orochi, Golds, Negidals, Ainu]. Khabarovsk: Dal'giz, 1933, 740 p. (in Russian).

35. Smolyak A.V. Shaman: lichnost', funktsii, mirovozzreniye (narody Nizhnego Amura) [The Shaman: Personality, Functions, Worldview (the Peoples of the Lower Amur)]. Moscow: Nauka, 1991, 279 p. (in Russian).

36. Stepanoff C. Chamanisme, ritual et cognition chez les Touvas (Sibérie du Sud) [Shamanism, Ritual, and Cognition among the Tuva (Southern Siberia)]. Paris: MSH, 2002, 406 p. (in French).

37. Tokarev S.A. Rannie formy religii i ikh razvitie [The Early Forms of Religions and Their Evolution]. Moscow: Nauka, 1964, 399 p. (in Russian).

38. Tugolukov V.A. Polevye issledovaniia Institut Etnografii $i$ Antropologii [Fieldwork Research of the Institute of Ethnography and Anthropology]. Moscow: Nauka, 1975, no. 2, pp. 36-44 (in Russian).

39. Varlamov A., Galina K., Lavrillier A. Electronic Devices for Safeguarding Indigenous Languages and Cultures (Eastern Siberia). 2020. In Routledge Handbook of Indigenous Peoples in the Arctic. London and NY: Routledge, pp. 58-75.

40. Vasilevich G.M. Sbornik Muzeia Anthropologii i Etnografii [Anthology of the Museum of Anthropology and Ethnography]. 1957, no. 1 (XVII), pp. 151-185 (in Russian).

41. Vasilevich G.M. Etnografiia [Ethnography]. 1930, no. II (3), pp. 57-67 (in Russian).

42. Vaté V. Kilvêi: The Chukchi Spring Festival in Urban and Rural Contexts. In Rebuilding Identities: Pathways to Reform in Post-Soviet Siberia. Erich Kasten, ed. Berlin: Dietrich Reimer Verlag, 2005, pp. 39-62.

43. Vitebsky P., Alekseev A. Annual Review of Anthropology. 2015, no. 44, pp. 439-455.

44. Zabiyako A.P., et al. Evenki Priamur'ia: olennaia tropa istorii i kul'tury [The Evenki of Priamurie: The Deer Trail of History and Culture]. Blagoveshchensk: AMGU, 2012, 384 p. (in Russian).

Submitted for publication: March 22, 2021. Accepted for publication: August 2, 2021 Published: September 28, 2021. 